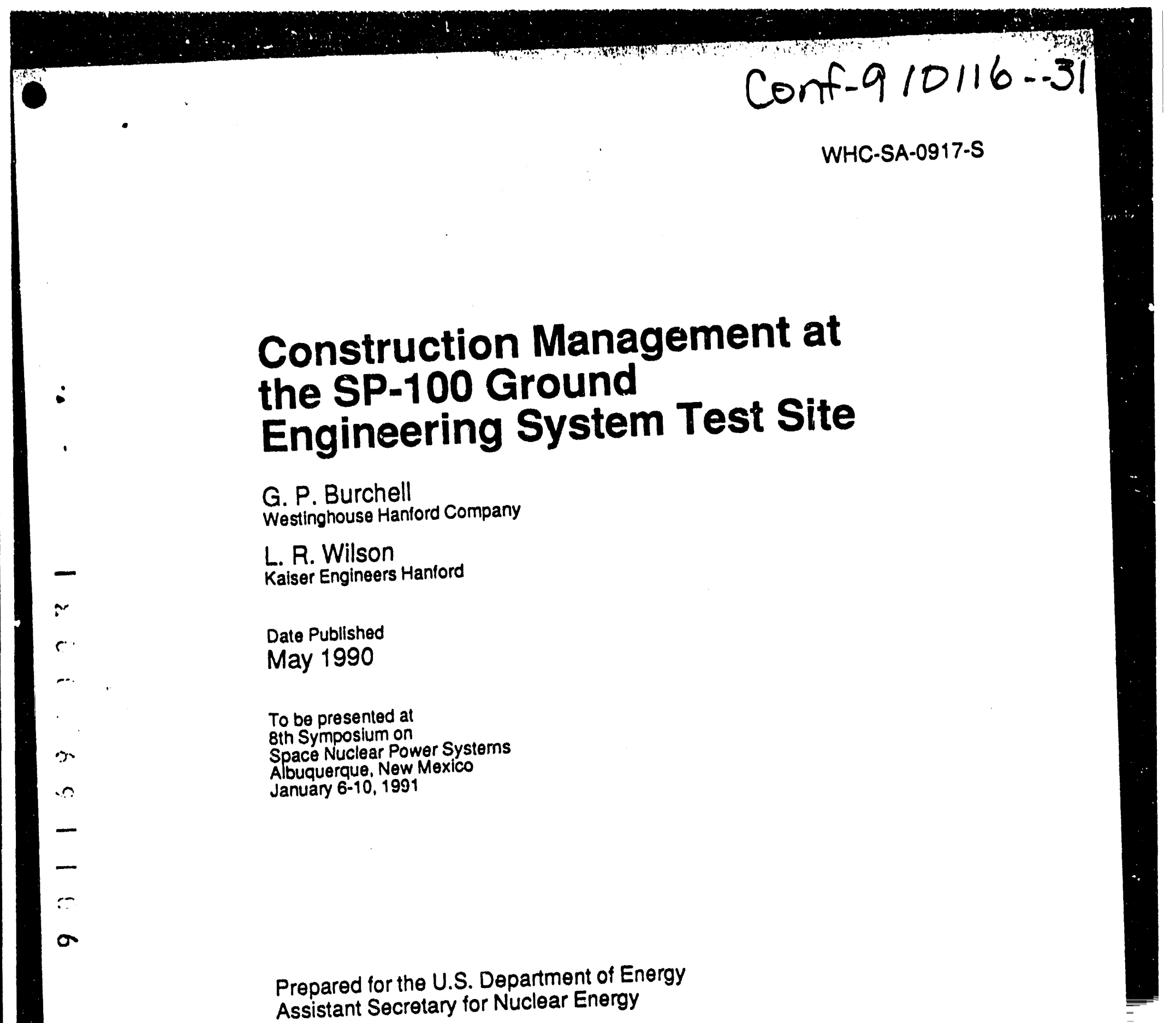

Prepared for the U.S. Department of Energy

(2) Westinghouse P.O. Box 1970 Hantord Company Richland. Washington 99352

Hunford Operations and Enpineering Contractor tor the 10930

U.S. Department of Energy under Contract DE-ACO6-87RL10930

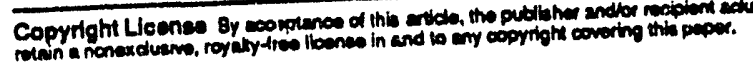

MASTER

Approved for Public Release

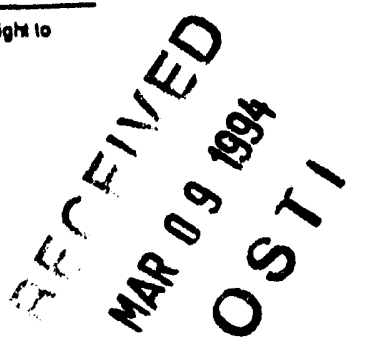


Wh+and
.

N

\section{DISCLAIMER}

This roport was prepared as an account of work sponsored by an agency of the United States Government. Neither the United States Government nor any ageney thereol, nor any of thoir employees, nor any of their contractors, subcontractors of their employeos, makes any warrenty, expresesed of implled. of aseumes any legal llability or responsibillty for the accuracy, comploteness, or any third party's use or the resulte of such use of any information, apparatus, product, of process disclosed, of represents that its use would not intringe privately owned rights. Relorence herein to any specific commercial product, process, or service by trade name. trademark, manulacturep, or othenwise, does nol necuesarily constitute or imply its endorsement, recommendation, of favoring by the United States Governmont ot any agency thereol or its contractors or subcontractors. The views and opinions of authors expressed herein do nol necessarily state or reflect those of the Unitad Stales Government of any agency thereol.

Printed in the Unlied Sutos of Amaries

DISCLU.2.CHP (2.49) 


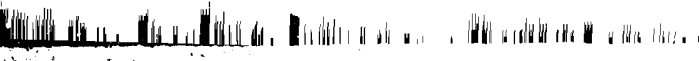

\title{
CONSTRUCTION MANAGEMENT AT THE SP-100 GROUND ENGINEERING SYSTEM TEST SITE
}

\author{
Gail P. Burchell \\ Westinghouse Hanford Company \\ Post Office Box 1970 \\ Richland, WA 99352 \\ (509) 376-6202 \\ Lloyd R. Wilson \\ Katser Engineers Hanford \\ Post Office Box 888 \\ Richland, WA $\$ 9352$
}

(509) 376-3606

$m$
$\because$
$r$
$r$
-
$=$
0

\section{INTRODUCTION}

The SP-100 Ground Engineering System (GES) Test Site is planned for construction at the U.S. Department of Energy's Hanford Site in Southeastern Washington. This project provides the Hanford Site contractors with a unique opportunity to showcase a number of design and construction innovations that significantly lower the design and construction costs while providing a facility that will effectively meet all of its design objectives.

This paper will explain the organization and management of the SP-100 project, specifically those activities relating to facilit.y design modifications and construction management, as performed through the joint efforts of Westinghouse Hanford Company (Westinghouse Hanford) and Kaiser Engineers Hanford (KEH).

\section{ORGANIZATION AND RESPONSIBILITIES}

The SP-100 GES Test Site Facility design and construction activities are managed within the framework of the Hanford Site project management system. The U.S. Department of Energy Richland Operations Office (DOE-RL) provides overail project management and coordinates the activities of the prime contractors. The SP-100 GES Test Site activities are managed through the Assistant Manager for Environmental Management, by the Technical Services Branch of the DOE-RL Project Management Division.

As the Operations and Engineering Contractor and principal performer on the SP-100 GES Test Site, Westinghouse Hanford has a staff dedicated to the overall construction management of this major project. Westinghouse Hanford is the focal point for construction planning, coordination, technical direction, and integration with other public or private agencies involved with the SP-100 project, whether at the Hanford Site or at other government installations. 
As the Hanford Site Engineer/Constructor Contractor, KEH will provide architectural and enrineering services for bullding and utility modifications and will manage and perform construction activities, either through a combination of fixed-price competitively bid subcontract packages, or through its own construction forces. Work that is well defined and not subject to change will be performed by subcontractors; KEH construction forces will perform work of a more uncertain nature, such as work in contaminated areas.

A number of initiatives and innovations for the existing Hanford Site management systems are being used to manage the facllity modification effort. These management initiatives and approaches to new projects have enabled the Hanford Site construction forces to perform in examplary fashion in recent projects such as the following:

?

Well installation in support of the Comprehensive Environmental Response, Compensation, and Liability Act and the Resource Conservation and Recovery Act groundwater studies in potentially or actually contaminated sites.

- Asbestos removal and replacement projects required to upgrade aging Management system innovations are outlined in the following paragraphs.

\section{Dedicated Team Approach}

The most important innovation is the concept of a dedicated SP-100 project team, as opposed to the conventional matrixed organization. Personnel assigned to the project are dedicated to SP-100 and cannot be removed, reassigned, or assigned to projects in addition to SP-100 without the knowledge and consent of the project manager. This dedicated team approach fosters an attitude of project ownership and facilitates closer communication and coordination among the various design disciplines.

A significant amount of thought and effort was put into staffing this dedicated team. Individuals were hand-picked for their specific skills and experiences relevant to the project, particularly experience in the commercial nuclear industry sector. As part of this recruitment endeavor, KEH reached outside of the traditional Hanford environment to find a project manager with extensive experience in the commercial nuclear industry who could bring fresh insight and innovation to the management of the SP-100 project.

Every effort is being made to provide this team with the environment and tools necessary to nurture maximum productivity. This includes locating the design team near construction activities and making sure enginears have the right equipment to do their jobs properly. 


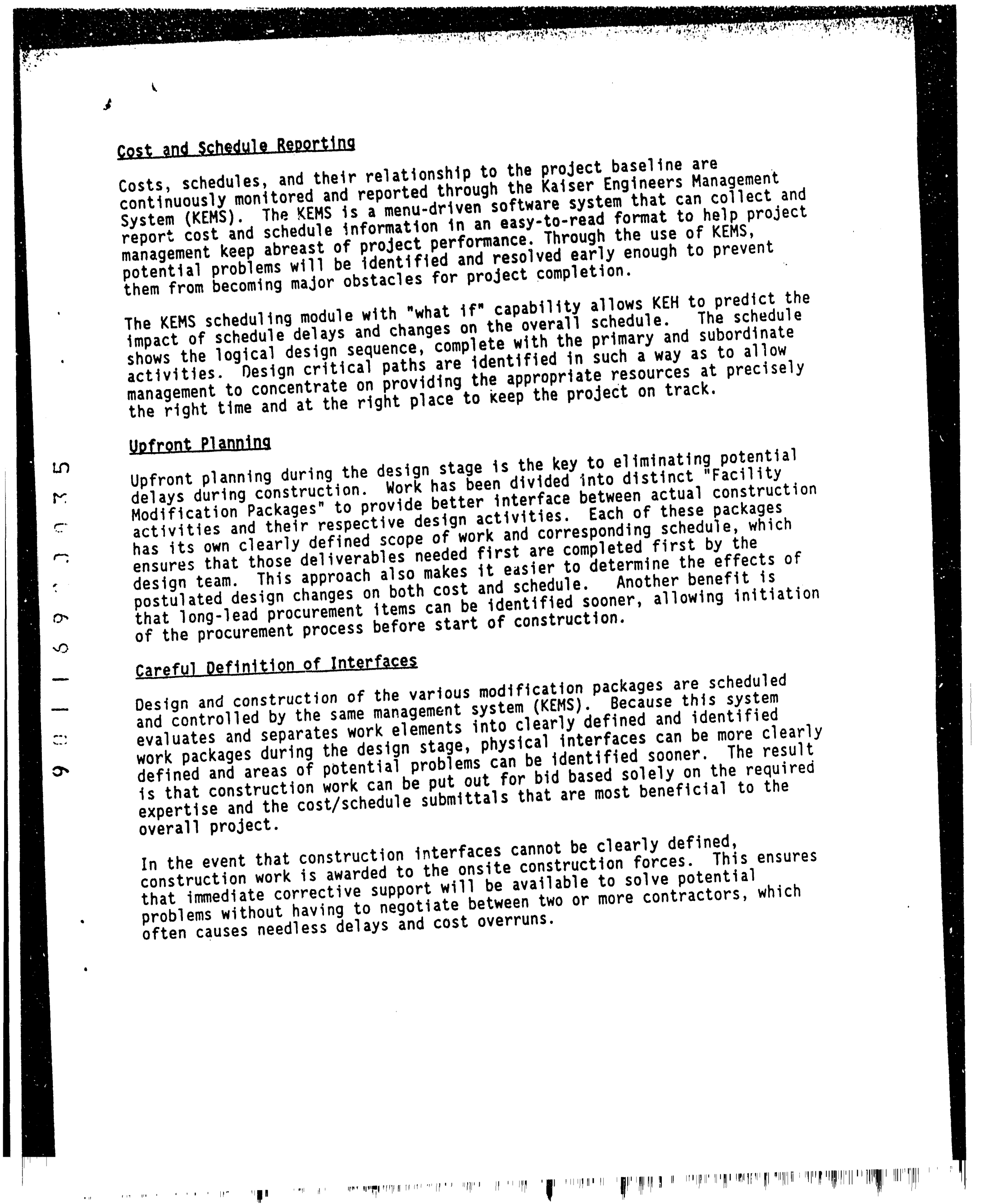


The interface between construction and engineering is initiated as soon in the design process as possible. Through perlodic constructibility reviews and input from construction management throughout the design process, potential problems and unforseen interferences during construction are greatly reduced.

Communication among the various engineering disciplines is also improved. Frequent interdisciplinary reviews are held for engineers to review progress and the coordination of their work with the other disciplines. This ensures a better product by minimizing design review comments, design verification problems and interferences, and common interface problems, such as poor comunication.

\section{SUMMARY}

The construction management approach used by the project team for the SP-100 GES Test Site provides the optimum construction deliverable. The success of this effort can be attributed to the innovations, proven successfut on environmentally sensitive projects, that transcend traditional Hanford Site construction activities:

- A dedicated project team that remains with the project through a completed phase or package.

- Accurate and up-to-date cost and schedule performance reporting through the KEMS computer system.

- Careful, upfront planning of the design and construction activities through the use of packages with logical and clearly defined scopes.

- Clearly defined and evaluated physical and design interfaces during the early phases of the project. 

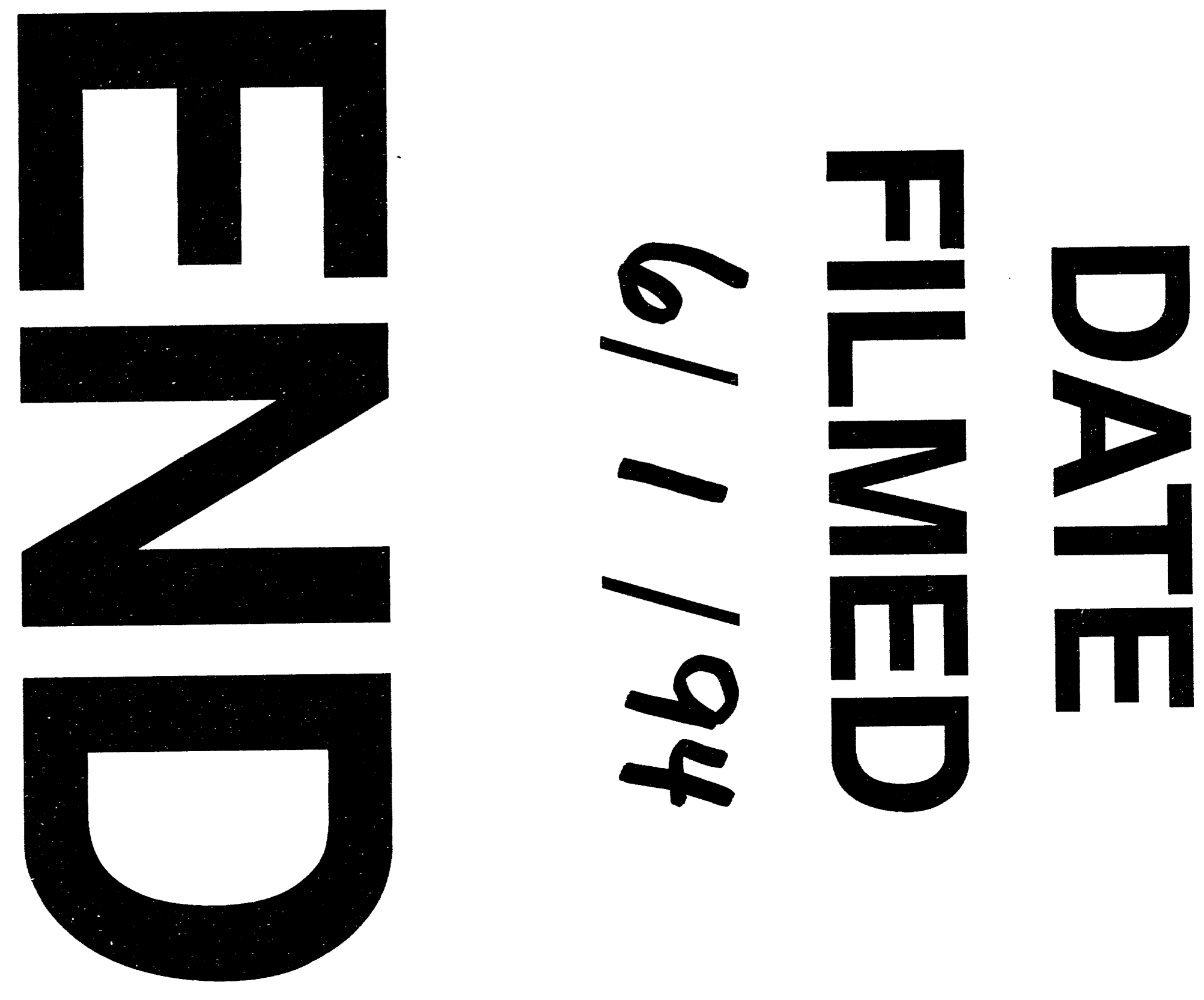


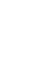

